\title{
The Effects of Information Communication Technology on Stock Market Capitalization: A Panel Data Analysis
}

\author{
Dr. Sang Lee \\ Dept. of Management and Business Administration, Southeastern Louisiana University \\ SLU 10813, Hammond, LA 70402, USA \\ Tel: 1-985-549-2086Ｅ-mail: Sang.Lee@ southeastern.edu
}

Dr. Matthew Alford

Dept. of Management and Business Administration, Southeastern Louisiana University

SLU 10813, Hammond, LA 70402, USA

Tel: 1-985-549-3091Ｅ-mail: Matthew.Alford@ southeastern.edu

Dr. John Cresson

Dept. of Accounting and Finance, Southeastern Louisiana University

SLU 10468, Hammond, LA 70402, USA

Tel: 1-985-549-2146 E-mail: jcresson@ southeastern.edu

Dr. Lara Gardner (Corresponding author)

Dept. of Management and Business Administration, Southeastern Louisiana University

SLU 10813, Hammond, LA 70402, USA

Tel: 1-985-549-3068Ｅ-mail: Lara.Gardner@selu.edu

Received: March 14, 2017 Accepted: March 30, 2017

doi:10.5296/ber.v7i1.10936 URL: https://doi.org/10.5296/ber.v7i1.10936

\section{Abstract}

The level of investment in information communication technologies (ICT) that may affect 
stock market capitalization varies substantially across countries. Using data on 81 countries from 1998 to 2014, we use a country-fixed effects model to estimate the relationship between ICTs and stock market capitalization. Our empirical model is built on the premise that (1) increased deployment of ICT allows financial market participants to make more informed decisions at reduced inherent risks associated with deficient information or uncertainty in financial markets; and (2) increased access to and use of information communication technologies is expected to improve a country's economic fundamentals. The empirical results support our hypothesis that ICT expansions are positively associated with stock market capitalization.

Keywords: Information communication technology, Stock market capitalization, Economic growth

\section{Introduction}

Since the pioneering work of Hardy (1980) which examined the relationship between Gross Domestic Product (GDP) and the number of telephone lines per person using data on 45 countries over 1960-1973, there has been a vast amount of literature on the relationship between the deployment of telecommunications technologies and economic growth. From an early research focus on the penetration of conventional land-line telephones in the 1980s and early 1990s to mobile telephony and broadband internet expansions in recent years, researchers and policymakers alike have attempted to examine how increased penetrations and advances in telecommunications technologies specifically impact economic development. Although modern information communication technologies (ICT) has long become an indispensable part of our daily lives, especially in most developing and developed economies, its role in the economic development of a country or region continues to remain a topic of growing research interest not only because there still are regions where access to modern ICT is limited, but also because ICT continues to advance, creating more wealth-creating opportunities.

There are many reasons to expect that a country's investment in information communication technologies could result in improved economic growth. In his seminal paper, Leff (1984) argued that increased availability of modern telecommunications can reduce the cost of transmitting information, and it in turn will make more information available to decision makers, so individual participants as well as organizations can make more rational decisions, leading to improved performances. In this study, we build our conceptual analytical framework on Leff (1984) and Aker and Mbiti (2010) and aim to extend the current literature on the causal links between ICT expansions and economic development by investigating specifically how expansions of ICT such as mobile telephony and broadband internet services have affected a country's market capitalization. Our results indicate that the number of mobile cell subscriptions, internet users, and fixed broadband subscriptions per 100 people each have a positive and statistically strong effect on market capitalization.

The rest of this paper is organized as follows. In the following section we discuss relevant previous literature. In Section 3 a theoretical framework is introduced to illustrate the importance of time-efficient access to and use of business or economic information to the 
success of financial markets. In Section 4, we discuss the data and develop an empirical regression model. The discussion of regression results and concluding remarks follow in Section 5 .

\section{Literature Review}

In previous literature, the study of the relationship between communication technologies (including modern ICT) and economic growth has been conducted largely in two ways. First, a number of studies have investigated whether there exists a statistically significant positive relationship between ICT expansions and economic growth. In a seminal study, Cronin, Parker, Colleran and Gold (1991) examined time series data from the U.S. over the time period 1958-1988 and found that there were two-way beneficial effects between the U.S. economy and telecommunications investments. In an ensuing study, Cronin, Colleran, Herbert and Lewitzky (1993) analyzed U.S. data from 1958 to 1990 and obtained empirical evidence that telecommunications advancements positively contributed to aggregate and sectoral productivity growth rates. Madden and Savage (1998) is another empirical study that confirmed two-way mutual causal relationship between the investment in telecommunications infrastructure and economic growth in transitional economies in Central and Eastern Europe (CEE).

Empirical findings were often mixed or conflicting depending on data or empirical specifications. For instance, Beil, Ford, and Jackson (2005) performed causality tests using the U.S. data on real GDP and real telecommunications investment from 1947 to 1996. They found a one-way positive effect from real GDP to real telecommunications investment, rather than an effect from ICT investment to GDP. On the other hand, Wolde-Rufael (2007), which applied a modified Granger-causality test to the same data used in Beil, Ford, and Jackson (2005), found two-way causality between economic growth and telecommunications investment.

More recently, Arvin and Pradhan (2014) attempted to confirm Granger causal relationships between broadband penetration and economic growth among others. Their analysis of panel data from the G-20 countries for the period 1998-2011 revealed short-run bi-directional causality between broadband penetration and economic growth among the more developed countries within the G-20. Empirical investigations in this subgroup of the literature employed time series techniques to confirm the presence of any causal directions and measure the strength of such relationships between communication technologies and economic growth. However, their policy implications are limited in that causality tests do not allow the measurement of marginal effects between them.

In parallel with applications of time series techniques such as Granger causality tests to the relationship between information communication technologies (ICT) and economic growth, there has been a growing use of econometric models that lay emphasis on the potential endogeneity between ICT penetrations and economic growth. In an early effort to measure the magnitude of the impact of telephone penetrations on GDP, Norton (1992) examined cross-sectional data from 47 countries over the 1957-1977 time period and concluded that "telephones provide substantial growth- and investment-enhancing activity and thus facilitate 
economic growth" (p. 192). Roller and Waverman (2001) was a milestone in the literature in that they estimated a simultaneous system of four equations that combined a macro production function with a micromodel for telecommunication investment. Using data from 21 OECD countries over a 20-year period, their joint estimation yielded evidence of a significant positive impact of telecom on economic growth, especially among developed economies. Datta and Agarwal (2004) also investigated the long-run relationship between telecommunication investment and economic growth using data from 22 OECD countries over the period 1980-1992. They regressed the growth rate of real GDP per capita on the number of telephone lines per 100 inhabitants along with other control variables in a single regression equation model. The regression results indicated a strong and positive correlation between telecommunications infrastructure and economic growth.

Note that the deployment of broadband lines, which is viewed as a technological breakthrough compared to conventional telecommunications infrastructure, has increased rapidly since the late 1990s. As a result, the scope of recent empirical studies on the relationship between the deployment of broadband lines and economic growth has largely been based on OECD countries. Crandall, Lehr, and Litan (2007) examined cross-sectional data from 48 U.S. states and tested the proposition that employment and output depend on the number of broadband lines per 100 persons along with other factors that account for differences in growth across states. Their regression results showed that at the state-level, non-farm private output was positively correlated with broadband penetration, but statistically insignificant. Koutroumpis (2009) investigated how the deployment of broadband lines affected economic growth among 22 OECD countries for the time period 2002-2007 while controlling for two-way causal relationships between economic growth and telecommunications infrastructure. The result of a simultaneous equations model suggested that there was a significant and positive impact on economic growth of broadband infrastructure.

Czernich, Falck, Kretschmer, and Woessmann (2011) also estimated the effect of broadband penetration on economic growth for 25 OECD countries in 1996-2007, and found that "an increase in the broadband penetration by 10 percentage points raised annual per capita growth by 0.9-1.5 percentage points" (p. 530). In a similar fashion, Bojnec and Ferto (2012) used a dynamic panel model with the system of Generalized Method of Moments (GMM) to measure the effect of broadband availability on economic growth among 34 OECD countries over years 1998-2009. Contrary to many previous studies, they did not find empirical findings that support a significant and positive correlation between total broadband per person and real GDP per capita.

Some studies focused on a noticeable asymmetry in penetration of land-line and mobile phones, especially in less developed regions. Lee, Levendis and Gutierrez (2012) examined data covering 44 sub-Saharan countries over the years 1975 to 2006. Using the two-step difference GMM estimator of Arellano and Bover (1995), they found a significant and positive contribution to economic growth of mobile phone expansions in the region. In another regional study, Levendis and Lee (2012) focused on 29 countries in Asia over 26 sample years from 1981 to 2006, and found that the number of land-line phones per 100 
persons had a positive impact on economic growth during the sample period.

\section{Theoretical Framework}

Differing from most empirical studies in the literature, the scope of this study is confined to the role of ICT in the growth of market capitalization for two reasons. First, financial markets (we will use financial markets and stock markets interchangeably hereinafter) often mirror a country's current economic performance as well as its future outlook. And all participants in the financial markets are exposed to a certain level of inherent uncertainty, because they are often not fully informed of concurrent events of economic importance or they are limited in their capacity to predict future events. If "the antidote for uncertainty is [indeed] additional information" (Leff, 1984, p. 257), financial markets may be one of the greatest beneficiaries of modern information communication technologies (ICT) inasmuch as risks associated with deficient information or uncertainty may be pronounced the most in financial markets. There is much anecdotal evidence of the opportunity costs associated with deficient or loss of access to ICT. When the airline Virgin Blue's online booking systems went down for a period of 11 days in September 2010, affecting about 50000 passengers and 400 flights, the company's loss associated with its information technology outages was estimated to amount to $\$ 20$ million. ${ }^{1}$ On a more dramatic note, in a 2012 study the Ponemon Institute reported that the average company's cost for every minute of internet outage could cost from as little as $\$ 1$ to more than $\$ 100000 .^{2}$

Second, as the stock market is often considered the first-hand barometer of the overall performance of an economy, it is presumed in this study that ICT expansions also indirectly benefit financial markets to the extent that ICT promotes a country's overall economic growth. Aker and Mbiti (2010) identified five potential mechanisms through which adoption and use of mobile telephones foster economic development as follows: (i) mobile phones reduce search costs and improve coordination between business activities, leading to an increase market efficiency; (ii) increased communication through mobile phones helps businesses to better manage their supply chains, resulting in a gain in productive efficiency; (iii) increased use of mobile telephones and its attendant demand for mobile-related services provide additional income- or wealth-creating opportunities; (iv) reduction in communication costs by mobile phones allow economic participants to respond better to shocks through increased speed of information flows; and (v) mobile phone-based applications and innovative development projects can further advance GDP growth.

Although Aker and Mbiti (2010) examined the economic consequences of mobile phone usage in sub-Saharan Africa, its economic reasoning can be extended to countries of all stages of economic development as well as to other means of advanced ICT such as broadband internet services. Building on Leff (1984), Aker and Mbiti (2010) and Aker, Ksoll, and Lybbert (2012), we presume that the expansion of ICT is positively correlated with the growth of a country's financial markets in two ways. First, increased deployment of ICT may directly help financial markets to grow. ICT expansions allow all participants in financial

\footnotetext{
${ }^{1} \mathrm{https} / / / \mathrm{www}$. evolven.com/blog/downtime-outages-and-failures-understanding-their-true-costs.html

2 http://www.theatlantic.com/technology/archive/2016/10/a-lot/505025/
} 
markets to stay current with ongoing economic status and performance updates concerning domestic companies, thereby reducing inherent risk in financial markets and making financial investments more attractive. Second, increased access to and use of information through ICT expansions may improve the economic fundamentals of a country, resulting in economic growth in the long run. And such ICT-induced economic growth in turn will increase household consumption and business investment expenditures, thereby fostering the growth of financial markets.

\section{Empirical Model and Data}

We estimate a model of the determinants of market capitalization in 81 countries between 1998 and 2014. Country fixed effects are included in the estimated equation to control for country-specific unobserved attributes that do not vary over time:

$$
S T O C K_{i t} / G D P_{i t}=\alpha+\gamma I C T_{i t}+\delta E C O N_{-} F R E E D O M+\boldsymbol{X}_{i t}^{v} \boldsymbol{\beta}+\mu_{i}
$$

where

$$
\mathbf{X}_{\mathrm{it}}^{v}=\left[\frac{G O V T_{i t}}{G D P_{i t}}, \frac{F D I_{i t}}{G D P_{i t}}, P O P 15-64_{i t}, R E C 2008-2009_{i t}\right]
$$

and

$$
E\left[v_{i t}\right]=E\left[\mu_{i} v_{i t}\right]=0
$$

Our dependent variable $\left(S T O C K_{i} / G D P_{i t}\right)$ is the market capitalization of listed domestic companies, as a percent of GDP, in country $i$ at time $t ; I C T_{i}$, is the information communication technology within country $i$ at time $t$, and ECON_FREEDOM is a measure of the economic freedom of markets within each country. Three specifications for $I C T_{i t}$ are considered: the number of mobile cell subscriptions per 100 people $\left(M O B I L E_{i t}\right)$, the number of internet users per 100 people (INTERNET $T_{i t}$ ), and the number of fixed broadband subscriptions per 100 people $\left(B R O A D B A N D_{i t}\right)$. Since these three measures of information and communication technologies are highly correlated, only one type of ICT is controlled in each regression equation.

We also explore two measures of a country's economic freedom which are indexes of the economy's freedom from government laws and regulations. The variable Financial Freedom is a measure of the financial sector's independence from government control and interference, encompassing the five fundamental aspects of financial markets such as the extent of government regulation of financial services, the degree of state intervention in banks and other financial firms through direct and indirect ownership, government influences on the allocation of credit, the extend of financial and capital market development, and openness to foreign competition (http://www.heritage.org/index/). The index values for the variable Monetary Freedom are based on a weighted average of the inflation rate for the most recent three years and the extent of price controls in the country, where the weighted average 
inflation rate is the primary determinant of the index (http://www.heritage.org/index/). In this study, we assume that a country's long-term stock market growth is partly premised on conditions that its financial sector is functionally efficient as well as relatively independent from institutional and governmental obstacles to free decision-makings by stock market participants. Both these indexes of economic freedom are hypothesized to have a positive relationship with market capitalization.

Among the control variables included in $\boldsymbol{X}_{i t}^{\prime}$, the variable $G O V T_{i t} / G D P_{i t}$ is the government's final consumption expenditure as a percent of its GDP within the country. This variable is a proxy for how government-centered a country's economy is, and varies over time. Our presumption is that a country's stock market capitalization relative to its GDP tends to be smaller when the government's share of GDP is larger. The variable $F D I_{i t} / G D P_{i t}$ is the net inflow of foreign direct investment (FDI) as a percent of the country's GDP and is included to control for the level of openness or globalization of a country's financial sector. This variable is expected to be positively correlated with the dependent variable. The variable POP15-64 is a proxy for a country's demographic characteristics and measures the percent of a country's total population that is between the ages of 15 and 64. Assuming that population between the ages 15 to 64 is the number of people who could potentially be economically active, we hypothesize that a country's stock market capitalization relative to its GDP tends to be greater when its total population between the ages of 15 and 64 is greater.

In 2008 and 2009 many countries experienced a financial crisis, which may have disrupted stock market capitalization within the countries and the relationship between ICT and stock market capitalization. To capture differences in stock market capitalization trends before and after the Great Recession, we include a dummy variable REC2008 - 2009 it which is equal to one if the year is 2008 or 2009 and 0 otherwise. Since the values of financial markets around the world decreased substantially during this time period, we expect the relationship between REC2008 - 2009 ${ }_{i t}$ and market capitalization to be strongly negative.

Our unobserved country-specific effects are denoted by $\mu_{i}$, and these effects are time-invariant. These may capture unobserved traits such as the level of trust a country's population has in the efficiency of markets, if that level of trust is unchanging over time. In each period, a country is also subject to its own idiosyncratic shocks, denoted by $v_{i t}$. The country-specific and idiosyncratic shocks are assumed to not be correlated with each other.

All data, with the exception of the economic freedom measures, are from the World Bank's World Development Indicators for 1998 to 2014. There are 81 countries that have values for all explanatory variables, including all three measures of information communication technology. However, for these 81 countries, the number of years for which data are available depend on which ICT measure is used: there are 1117 observations for the 81 countries when $M O B I L E_{i t}$ is the ICT measure, there are 1105 observations for the 81 countries when $I_{\text {INTERNET }}$ it is the measure of ICT, and there are 935 observations for the 81 countries when $B R O A D B A N D_{i t}$ is the measure of ICT. The indexes of economic freedom are compiled by the Heritage Foundation (http://www.heritage.org/index/). The summary statistics for all variables are provided in Table 1. 


\section{MInstitute Macrothink $_{\text {Intion }}$}

Business and Economic Research ISSN 2162-4860

Given the panel nature of our data, we use a panel estimator to generate coefficient estimates for our explanatory variables. The inclusion of country-specific fixed effects in Equation (1) allows us to control for omitted variables that differ between countries but are constant over time. However, while a fixed-effects estimator will give consistent results, the results may not be more efficient than a random-effects estimator. Therefore, we also fitted Equation (1) with random effects. Coefficient results from the random-effects and the fixed-effects estimates of Equation (1) are very similar in sign and statistical significance. We then used the Hausman test to test the null hypothesis that the coefficient estimates from the random-effects model are the same as the estimates from the fixed-effects estimator. Results from the null hypothesis rejected the null hypothesis that the coefficient estimates from the fixed-effects estimator and the random-effects estimator are the same with a statistically significant p-value of 0.000 , indicating that the fixed-effects estimator should be used. The null hypothesis was rejected for all six specifications of Equation (1) in Table 2.

Table 1. Summary Statistics (1998 - 2014)

\begin{tabular}{|l|c|c|c|c|}
\hline & Mean & Standard deviation & Minimum & Maximum \\
\hline STOCK $_{\text {it }} /$ GDP $_{\text {it }}$ & 63.47 & 107.40 & 0.01 & 1254.47 \\
\hline MOBILE $_{\text {it }}$ & 72.26 & 46.38 & 0.02 & 237.35 \\
\hline INTERNET $_{\text {it }}$ & 33.87 & 27.53 & 0.004 & 96.30 \\
\hline BROADBAND $_{\text {it }}$ & 9.90 & 11.11 & 0 & 42.56 \\
\hline Financial Freedom & 58.77 & 17.27 & 10 & 90 \\
\hline Monetary Freedom & 77.15 & 9.81 & 0 & 95.40 \\
\hline GOVT $_{\text {it }} /$ GDP $_{\text {it }}$ & 15.67 & 4.59 & 4.85 & 28.05 \\
\hline FDI $_{\text {it }} /$ GDP $_{\text {it }}$ & 5.61 & 11.04 & -58.98 & 173.45 \\
\hline POP15 - 64 $_{\text {it }}$ & 65.67 & 5.55 & 47.91 & 85.96 \\
\hline REC2008 - 2009 $_{\text {it }}$ & 0.14 & 0.35 & 0 & 1 \\
\hline Note: These summary statistics are for 81 countries, resulting in 1 117 observations. \\
\hline
\end{tabular}

\section{Results and Concluding Remarks}

Results from the estimation of Equation (1) are shown in Table 2. Six sets of results are presented in the table, for each of the six possible combinations of three types of information communication technology and two indexes of economic freedom. The coefficient estimates for all three measures of ICT are positive and statistically significant at the one-percent level. 
The number of mobile cell subscriptions, internet users, and fixed broadband subscriptions per 100 people each have a positive and statistically strong effect on market capitalization. Surprisingly, the coefficient estimates on the two measures of economic freedom are statistically insignificant in all models except Regression (6).

Large, negative and statistically significant coefficient estimates of the variable $G O V T_{i t}$ / $G D P_{i t}$ are consistent with the presumption that a country with a relatively large government share of GDP tends to have relatively lower levels of stock market capitalization. The coefficient estimates for the variables $F D I_{i t} / G D P_{i t}$ and $P O P 15-64_{i t}$ are also consistent with our hypotheses, given the positive effects of these variables on market capitalization. As Table 2. Estimation Results from Six Fixed-Effects Regressions

\begin{tabular}{|c|c|c|c|c|c|c|}
\hline & $\begin{array}{c}\text { Regression } \\
\text { (1) }\end{array}$ & $\begin{array}{c}\text { Regression } \\
\text { (2) }\end{array}$ & $\begin{array}{c}\text { Regression } \\
\text { (3) }\end{array}$ & $\begin{array}{c}\text { Regression } \\
(4)\end{array}$ & $\begin{array}{c}\text { Regression } \\
\text { (5) }\end{array}$ & $\begin{array}{c}\text { Regression } \\
\text { (6) }\end{array}$ \\
\hline$M O B I L E_{\text {it }}$ & $\begin{array}{l}0.323 * * * \\
(0.053)\end{array}$ & $\begin{array}{l}0.324 * * * \\
(0.053)\end{array}$ & & & & \\
\hline INTERNET $T_{\text {it }}$ & & & $\begin{array}{l}0.262 * * * \\
(0.105)\end{array}$ & $\begin{array}{l}0.265^{* * *} \\
(0.105)\end{array}$ & & \\
\hline$B R O A D B A N D_{\text {it }}$ & & & & & $\begin{array}{l}0.998 * * * \\
(0.247)\end{array}$ & $\begin{array}{l}1.106^{* * *} \\
(0.250)\end{array}$ \\
\hline$G O V T_{\text {it }} / G D P_{\text {it }}$ & $\begin{array}{l}-2.587 * * * \\
(1.019)\end{array}$ & $\begin{array}{l}-2.621 * * * \\
(1.014)\end{array}$ & $\begin{array}{l}-2.405 * * \\
(1.087) \\
\end{array}$ & $\begin{array}{l}-2.436 * * \\
(1.084) \\
\end{array}$ & $\begin{array}{l}-3.574 * * * \\
(1.363)\end{array}$ & $\begin{array}{l}-3.760 * * * \\
(1.334)\end{array}$ \\
\hline$F D I_{\text {it }} / G D P_{\text {it }}$ & $\begin{array}{l}0.458 * * * \\
(0.171)\end{array}$ & $\begin{array}{l}0.446 * * * \\
(0.172)\end{array}$ & $\begin{array}{l}0.505 * * * \\
(0.175)\end{array}$ & $\begin{array}{l}0.492 * * * \\
(0.175)\end{array}$ & $\begin{array}{l}0.466 * * * \\
(0.190)\end{array}$ & $\begin{array}{l}0.438 * * \\
(0.189)\end{array}$ \\
\hline POP $15-64_{\text {it }}$ & $\begin{array}{l}0.329 \\
(1.224) \\
\end{array}$ & $\begin{array}{l}0.293 \\
(1.219) \\
\end{array}$ & $\begin{array}{l}3.554 * * * \\
(1.114)\end{array}$ & $\begin{array}{l}3.521 * * * \\
(1.109)\end{array}$ & $\begin{array}{l}5.854 * * * \\
(1.453)\end{array}$ & $\begin{array}{l}6.166^{* * * *} \\
(1.441)\end{array}$ \\
\hline Financial Freedom & $\begin{array}{l}0.018 \\
(0.191)\end{array}$ & & $\begin{array}{l}0.013 \\
(0.198)\end{array}$ & & $\begin{array}{l}0.030 \\
(0.262)\end{array}$ & \\
\hline Monetary Freedom & & $\begin{array}{l}0.283 \\
(0.228) \\
\end{array}$ & & $\begin{array}{l}0.279 \\
(0.235) \\
\end{array}$ & & $\begin{array}{l}0.947^{* *} \\
(0.394) \\
\end{array}$ \\
\hline$R E C 2008-2009_{\text {it }}$ & $\begin{array}{l}-11.46^{* * *} \\
(4.500)\end{array}$ & $\begin{array}{l}-11.36 * * * \\
(4.497)\end{array}$ & $\begin{array}{l}-8.182 * \\
(4.561)\end{array}$ & $\begin{array}{l}-8.101 * \\
(4.559)\end{array}$ & $\begin{array}{l}-10.21 * * \\
(4.950)\end{array}$ & $\begin{array}{l}-9.827 * * \\
(4.935)\end{array}$ \\
\hline Constant & $\begin{array}{l}57.00 \\
(82.35) \\
\end{array}$ & $\begin{array}{l}39.12 \\
(83.54) \\
\end{array}$ & $\begin{array}{l}-143.4^{*} \\
(76.10) \\
\end{array}$ & $\begin{array}{l}161.6^{* * *} \\
(77.54) \\
\end{array}$ & $\begin{array}{l}-276.1 * * * \\
(98.89)\end{array}$ & $\begin{array}{l}-366.9 * * * \\
(105.5)\end{array}$ \\
\hline $\begin{array}{l}\text { Number of } \\
\text { Observations }\end{array}$ & 1117 & 1117 & 1105 & 1105 & 935 & 935 \\
\hline$R^{2}$ (overall) & 0.193 & 0.209 & 0.147 & 0.159 & 0.143 & 0.164 \\
\hline
\end{tabular}

expected, the Great Recession had a very strong negative impact on stock market capitalization in all models. This recession was caused by a major financial crisis, which severely decreased the value of many countries' stock markets. For example, the Dow Jones Industrial Index, a price-weighted average of 30 large companies on the New York Stock 


\section{MInstitute ${ }_{\text {Mnk }}^{\text {Macrothin }}$}

Business and Economic Research ISSN 2162-4860 2017, Vol. 7, No. 1

Exchange in the United States, lost over 54\% of its value between October of 2007 and March of 2009.

Among the six fixed-effects regressions in Table 2, Regression (2) produced the strongest measure of fit, with an overall $R^{2}$ of 0.209 . Regressions (1) and (2) include the most observations because values for $M O B I L E_{i t}$ are available for more years than are values for INTERNET $_{i t}$ and BROADBAND ${ }_{i t}$. These results suggest that the availability of information communication technologies is both statistically significant and positively correlated with market capitalization for these countries. The results are robust even after controlling for other explanatory variables.

In this study we attempted to provide empirical evidence of a positive association between expansions of information communication technologies and stock market capitalization on the premise that increased deployment of ICT contributes to the long-term growth of financial markets along multiple margins: (1) ICT expansions allow financial market participants to make better informed decisions at reduced inherent risks associated with deficient information or uncertainty in financial markets; and (2) as an economy becomes increasingly ICT-oriented, increased access to and use of information communication technologies will improve a country's economic fundamentals.

In future work we will explore the possibility of two-way effects between communication technology and the economy using fixed-effect instrumental variable estimations to control for the possible endogeneity of ICT. Also, while the current study has primarily focused on the impact of ICT on the size of market capitalization relative to GDP, it is equally conceivable that efficient flows of information affect the efficiency of the country's stock market. We believe this possibility offers an agenda for future research on the relationship between ICTs and stock market efficiency.

While ICT is a major driver of future economic growth, the concomitant growth of financial markets may be merely one of many ICT-induced economic expansions. In that regard, the current study's empirical findings of a positive impact of ICT expansions on stock market capitalization may shed insights for policy makers about why advances and expansions of ICT matter not just for financial markets but also for the economy as a whole.

\section{References}

Aker, J. C., Ksoll, C., \& Lybbert, T. J. (2012). Can Mobile Phones Improve Learning? Evidence from a Field Experiment in Niger. American Economic Journal: Applied Economics, 4(4), 94-120. https://doi.org/10.1257/app.4.4.94

Aker, J. C., \& Mbiti, I. M. (2010). Mobile Phones and Economic Development in Africa. Journal of Economic Perspectives, 24(3), 207-232. https://doi.org/10.1257/jep.24.3.207

Arellano, M., \& Bover, O. (1995). Another Look at the Instrumental Variables Estimation of Error-Components Models. Journal of Econometrics, 68(1), 29-51.

https://doi.org/10.1016/0304-4076(94)01642-D

Arvin, B. M., \& Pradhan, R. P. (2014). Broadband penetration and economic growth nexus: 
evidence from cross-country panel data. Applied Economics, 46(35), 4360-4369.

https://doi.org/10.1080/00036846.2014.957444

Beil, R. O., Ford, G. S., \& Jackson, J. D. (2005). On the Relationship Between Telecommunications Investment and Economic Growth in the United States. International Economic Journal, 19(1), 3-9. https://doi.org/10.1080/1351161042000320399

Bojnec, S., \& Ferto, I. (2012). Broadband availability and economic growth. Industrial Management and Data Systems, 112(9), 1292-1306.

https://doi.org/10.1108/02635571211278938

Crandall, R., Lehr, W., \& Litan, R. (2007). The Effects of Broadband Deployment on Output and Employment: A Cross- sectional analysis of U.S. Data. Issues in Economic Policy: The Brookings Institution, 6, 1-34 [Online] Available:

https://www.brookings.edu/wp-content/uploads/2016/06/06labor_crandall.pdf

Cronin, F., Colleran, E., Herbert, P., \& Lewitzky, S. (1993a). Telecommunications and Economic Growth: The Contribution of Telecommunications Infrastructure Investment to Aggregate and Sectoral Productivity, Telecommunications Policy, 17(9), 677-690.

https://doi.org/10.1016/0308-5961(93)90039-6

Cronin, F., Parker, E., Colleran, E., \& Gold, M. (1991). Telecommunications Infrastructure and Economic Growth: An Analysis of Causality, Telecommunications Policy, 15(6), 529-535. https://doi.org/10.1016/0308-5961(91)90007-X

Czernich, N., Falck, O., Kretschmer, T., \& Woessmann, L. (2011). Broadband Infrastructure and Economic Growth. The Economic Journal, 121(552), 505-532.

https://doi.org/10.1111/j.1468-0297.2011.02420.x

Datta, A. \& Agarwal, S. (2004). Telecommunications and Economic Growth: A Panel Data Approach. Applied Economics, 36(15), 1649-1654.

https://doi.org/10.1080/0003684042000218552

Hardy, A. P. (1980). The role of the telephone in economic development. Telecommunications Policy, 4, 278-286. https://doi.org/10.1016/0308-5961(80)90044-0

Heritage Foundation. (2017). http://www.heritage.org/index/

Koutroumpis, P. (2009). The economic impact of broadband on growth: A simultaneous approach. Telecommunications Policy, 33(9), 471-485.

https://doi.org/10.1016/j.telpol.2009.07.004

Lee, S. H., Levendis, J., \& Gutierrez, L. (2012). Telecommunications and Economic Growth: An Empirical Analysis of Sub-Saharan Africa. Applied Economics, 44(4), 461-469. https://doi.org/10.1080/00036846.2010.508730

Leff, N. (1984). Externalities, Information Costs, and Social Benefit-Cost Analysis for Economic Development: An Example from Telecommunications, Economic Development and Cultural Change, 32(2), 255-276. https://doi.org/10.1086/451385 


\section{Macrothink}

Business and Economic Research

ISSN 2162-4860 2017, Vol. 7, No. 1

Madden, G., \& Savage, S. J. (1998). CEE telecommunications investment and economic growth. Information Economics and Policy, 10, 173-195.

https://doi.org/10.1016/S0167-6245(97)00020-6

Norton, S. (1992). Transaction Costs, Telecommunications, and the Microeconomics of Macroeconomics Growth, Economic Development and Cultural Change, 41(1), 175-96. https://doi.org/10.1086/452002

Roller, L., \& Waverman, L. (2001). Telecommunications Infrastructure and Economic Development: A Simultaneous Approach. American Economic Review, 91(4), 909-923. https://doi.org/10.1257/aer.91.4.909

Wolde-Rufael, Y. (2007). Another Look at the Relationship between Telecommuications Investment and Economic Activity in the United States. International Economic Journal, 21(2), 199-205. https://doi.org/10.1080/10168730701345372

\section{Copyright Disclaimer}

Copyright for this article is retained by the author(s), with first publication rights granted to the journal.

This is an open-access article distributed under the terms and conditions of the Creative Commons Attribution license (http://creativecommons.org/licenses/by/3.0/). 